\title{
TINGKAT KECUKUPAN ZAT GIZI MAKRO DAN STATUS GIZI PASIEN TUBERKULOSIS DENGAN SPUTUM BTA (+) DAN SPUTUM BTA (-)
}

\author{
Rina Wasesa Aprilia Lazulfa ${ }^{1}$, Bambang Wirjatmadi², Merryana Adriani² \\ ${ }^{1}$ Program Studi S1 Kesehatan Masyarakat, Fakultas Kesehatan Masyarakat, Universitas Airlangga, Surabaya \\ ${ }^{2}$ Departemen Gizi Kesehatan, Fakultas Kesehatan Masyarakat, Universitas Airlangga, Surabaya \\ Email: rinawasesa@gmail.com
}

\begin{abstract}
ABSTRAK
Penyakit tuberkulosis merupakan penyakit infeksi menular akibat kuman mycobacterium tuberculosis. Kuman yang berupa droplet ini menular lewat percikan ludah yang keluar ketika batuk, bersin dan berbicara kemudian terhirup saat bernafas. Derajat kepositifan sputum Basil Tahan Asam (BTA) dari penderita menggambarkan semakin banyaknya kuman tuberkulosis di dalam paru yang berpotensi menularkan infeksinya. Pada umumnya penderita tuberkulosis ini mengalami penurunan nafsu makan hingga berdampak pada penurunan berat badannya. Penelitian ini termasuk penelitian comparative observasional analitik menggunakan metode pendekatan cross sectional dengan teknik simple random sampling yang dilakukan di Rumah Sakit Asy-Syaafi Pamekasan dengan jumlah sampel sebanyak 50 orang. Analisis data menggunakan uji Mann Whitney. Hasil penelitian memperlihatkan perbedaan yang signifikan pada tingkat kecukupan energi $(p=0,026)$, karbohidrat $(p=0,000)$, protein $(p=0,001)$, lemak $(p=0,029)$ dan status gizi $(p=0,022)$ antara kelompok tuberkulosis dengan sputum BTA (+) dan sputum BTA (-). Disimpulkan bahwa tingkat kecukupan (energi, protein, lemak dan karbohidrat) dan status gizi antara responden tuberkulosis sputum BTA $(+)$ memiliki perbedaan yang nyata dengan responden tuberkulosis sputum BTA (-).
\end{abstract}

Kata kunci: status gizi, tingkat kecukupan, tuberkulosis

\section{ABSTRACT}

Tuberculosis is an infectious disease caused by mycobacterium tuberculosis germs. Germs in form of droplets spread through saliva splashes out when coughing, sneezing and talking then inhaled during breathing. The degree of sputum smear positivity of patients describe the increasing number of tuberculosis bacteria in the lungs that could potentially transmit the infection. In general, patients with tuberculosis have decreased appetite which impact on weight loss. This research was comparative observational analytic research using cross sectional approach with simple random sampling conducted at the Hospital Asy-Syaafi Pamekasan with a sample size of 50 people. The results of Mann Whitney test showed a significant difference in adequacy level of energy $(p=0.026)$, carbohydrates $(p=0.000)$, protein $(p=0.001)$, fat $(p=0.029)$ and nutritional status $(p=0.022)$ between the groups of tuberculosis with sputum smear (+) and sputum smear (-). It was concluded that adequacy level (energy, protein, fat and carbohydrates) and nutrition status among respondents tuberculosis sputum smear (+) have significant differences with the respondent tuberculosis sputum smear (-).

Keywords: adequacy level, nutritional status, tuberculosis

\section{PENDAHULUAN}

Tuberkulosis masih menjadi trend topic golongan penyakit infeksi terbanyak di dunia. Pada tahun 2013 penyakit infeksi menular ini tercatat sebanyak 6,1 juta kasus baru tuberkulosis dengan jumlah orang baru yang didiagnosis tuberkulosis sebanyak 5,7 juta kasus dan 0,4 juta kasus lainnya sudah dalam masa pengobatan. Dalam beberapa tahun terakhir jumlah prevalensi penderita infeksi ini secara signifikan menurun, namun jumlah penderita infeksi tuberkulosis di Indonesia masih tergolong tinggi karena Indonesia menempati urutan terbanyak di dunia setelah Cina, India dan Afrika Selatan (WHO, 2014).

Hasil Riset Kesehatan Dasar (2013) mencatat jumlah yang sama dengan Hasil Riset Kesehatan Dasar (2010) yaitu pada jumlah prevalensi penduduk Indonesia yang di diagnosis tuberkulosis paru oleh tenaga kesehatan adalah sebesar $0,4 \%$ (Kemenkes, 2013). 
Menurut Mahdiana (2010) infeksi tuberkulosis masih menjadi masalah kesehatan bagi masyarakat Indonesia dengan lokasi infeksi primernya pada organ paru, namun tidak selamanya organ tubuh yang diserang oleh basil tuberkel ini adalah paruparu, tetapi dapat pula terjadi pada sendi atau tulang, ginjal, usus, rahim, dan getah bening (leher) yang dapat berdampak pada kematian (mortalitas). Terjangkitnya infeksi tuberkulosis ini ditandai dengan hasil pemeriksaan sputum Basil Tahan Asam (BTA) positif dengan mengumpulkan tiga spesimen dahak yaitu Sewaktu-Pagi-Sewaktu (SPS) dan foto toraks. Selain itu pemeriksaan sputum juga bertujuan untuk menentukan tingkat penularan infeksinya (Ben-Salma, et al., 2009).

Hasil pemeriksaan derajat positif $3(+++)$ merupakan gambaran adanya kuman tuberkulosis yang mengendap di dalam tubuh penderita dan menunjukkan semakin infeksius dalam menularkan infeksi tuberkulosis kepada orang sehat yang lainnya. Dalam hal ini penderita tuberkulosis paru berbeda dengan penderita tuberkulosis lainnya, infeksi tuberkulosis paru ini memiliki hasil pemeriksaan sputum BTA $(+)$ dan sputum BTA (-). Pemeriksaan sputum BTA dapat memberikan hasil yang berbeda dengan foto toraks. Foto toraks dapat memberikan gambaran radiologis dan penyokong diagnosis klinis dalam menegakkan diagnosis tuberkulosis paru, baik pada tuberkulosis paru BTA (+) ataupun BTA (-) (Srikanth, et al., 2009).

Faktor yang mempengaruhi kemungkinan seseorang menjadi pasien tuberkulosis adalah daya tahan tubuh yang rendah karena adanya infeksi HIV-AIDS dan malnutrisi. Faktor lainnya adalah faktor lingkungan, faktor perilaku, kesehatan perumahan, dan lama kontak serta konsentrasi kuman (Depkes RI, 2007).

Menurut Rukmini dan Chatarina (2011), penyakit infeksi tuberkulosis sebagai akibat dari aktifitas bakteri basil mycobacterium tuberculosis. Pada umumnya menyerang paru-paru karena penularan berupa droplet tersebut mencemari udara dan terhirup ketika bernafas. Tingkat keparahan penderita tuberkulosis dilihat dari jenis dan tingkat kepositifan dari sputum BTA, namun penyakit penyerta tidak dimiliki pada sebagian besar penderita yang memiliki sputum BTA derajat positif $3(+++)$ (Susilayanti, et al., 2014).
Menurut Manalu (2010), suatu pemeriksaan yang dilakukan secara aktif dapat mengurangi risiko infeksi penularan tuberkulosis paru, khususnya pada kelompok risiko tinggi dan penderita dengan status gizi kurang. Asupan atau konsumsi makan yang tidak cukup akan berdampak pada gizi kurang sehingga menyebabkan bibit penyakit masuk ke dalam tubuh dengan mudah dan dapat menyebabkan terjadinya penyakit infeksi. Infeksi ini memberikan dampak morbiditas dan mortalitas yang cukup tinggi bagi masyarakat. Pada umumnya penderita infeksi ini berusia produktif (15-55 tahun) dengan gejala utama malaise dan batuk dengan dahak $>2$ minggu (Al Arif, et al., 2015).

Kecenderungan penurunan berat badan penderita tuberkulosis merupakan akibat dari gejala anoreksia yang menyebabkan status gizi kurang (IMT<18,5). Kondisi ini dapat mengakibatkan terjadinya status gizi buruk apabila tidak diimbangi dengan diet yang tepat. Malnutrisi yang terjadi akan memperberat penyakit infeksinya, sehingga status gizi menjadi penyebab utama terjadinya kegagalan konversi pengobatan pada penderita infeksi tuberkulosis (Amaliah, 2012). Penelitian ini bertujuan untuk menentukan adanya perbedaan tingkat kecukupan zat gizi makro dan status gizi pasien tuberkulosis dengan sputum $\mathrm{BTA}(+)$ dan sputum BTA (-).

\section{METODE PENELITIAN}

Desain penelitian ini adalah penelitian comparative observasional analitik menggunakan studi cross sectional yang berlangsung selama satu bulan di RSU Asy-Syaafi Pamekasan. Populasi dalam penelitian ini adalah seluruh pasien tuberkulosis rawat inap yaitu sebanyak 105 orang dengan besar sampel sebanyak 50 orang, dengan kriteria inklusi yaitu penderita merupakan pasien rawat inap di RSU Asy-Syaafi dan di diagnosis tuberkulosis paru dengan BTA $(+)$ dan BTA (-) tanpa komplikasi penyakit lainnya. Pasien berusia 15-65 tahun dalam keadaan sadar (mampu berkomunikasi) dan bersedia menjadi responden. Pengambilan sampel dilakukan dengan menggunakan teknik secara simple random sampling. 
Data primer diperoleh secara langsung oleh peneliti meliputi: data karakteristik yaitu jenis kelamin dan usia responden, serta data tingkat kecukupan energi, protein, lemak dan karbohidrat. Data konsumsi pangan dikumpulkan dengan metode recall 2 x 24 jam menggunakan form recall 24 jam, baik makanan dari dalam Rumah Sakit maupun dari luar Rumah Sakit. Penentuan status gizi diukur dengan menimbang berat badan $(\mathrm{kg})$ dan mengukur tinggi badan $(\mathrm{cm})$ kemudian dimasukkan ke dalam rumus Indeks Massa Tubuh $(\mathrm{kg} / \mathrm{m} 2)$.

Status pasien berdasarkan jenis sputum BTA (+) maupun BTA (-) dikumpulkan dari data sekunder yakni dari rekam medik RSU AsySyaafi. Alat yang digunakan dalam penelitian ini meliputi: Microtoise dengan ketelitian 0,1 $\mathrm{cm}$ dengan kapasitas $200 \mathrm{~cm}$, timbangan injak dengan ketelitian 0,1 kg dengan kapasitas $120 \mathrm{~kg}$, kuesioner penelitian responden, form recall 24 jam, buku status pasien, dan nutrisurvey application.

Data hasil status gizi responden dikategorikan menjadi 3 kategori menurut Riskesdas (2010) yaitu: kurus (IMT $<18,5)$, normal $(24,9>$ IMT $\geq 18,5$ ) dan lebih (IMT $\geq 25$ ). Tingkat kecukupan zat gizi dikategorikan menjadi 3 kategori yaitu: kurang $(70-<80 \%)$, sedang $(80-99 \%)$, dan baik ( $\geq 100 \%$ ) (Supariasa, et al., 2014).

Data hasil pengkategorian tingkat kecukupan dan status gizi dianalisis menggunakan statistik uji Mann Whitney. Penelitian ini telah mendapat persetujuan dari komisi etik penelitian kesehatan Fakultas Kesehatan Masyarakat Universitas Airlangga No: 229-KEPK untuk melakukan penelitian yang melibatkan pasien tuberkulosis.

\section{HASIL DAN PEMBAHASAN}

Hasil penelitian observasi mengenai karakteristik responden (jenis kelamin dan usia), tingkat kecukupan (energi, protein, lemak dan karbohidrat) dan status gizi responden tuberkulosis yang masing-masing terbagi sebanyak 25 orang dengan sputum BTA $(+)$ dan 25 orang responden tuberkulosis dengan sputum BTA (-) serta hasil analisis uji Mann Whitney pada tingkat kecukupan dan status gizi responden disajikan pada tabel 1 dan 2 .
Tabel 1. Distribusi Karakteristik Responden Tuberkulosis dengan Sputum BTA (+) dan Sputum BTA (-)

\begin{tabular}{crrrrr}
\hline \multirow{2}{*}{ Karakteristik responden } & \multicolumn{4}{c}{ Tuberkulosis } \\
\cline { 3 - 6 } & \multicolumn{2}{c}{ BTA (+) } & \multicolumn{1}{c}{ BTA (-) } \\
\cline { 2 - 5 } & n & \% & n & $\%$ \\
\hline \multirow{2}{*}{ Jenis kelamin } & Laki-laki & 15 & 60 & 20 & 80 \\
& Perempuan & 10 & 40 & 50 & 20 \\
\hline \multirow{2}{*}{ Usia } & 18-29 tahun & 2 & 8 & 3 & 12 \\
& 30-49 tahun & 13 & 52 & 14 & 56 \\
& 50-65 tahun & 10 & 40 & 8 & 32 \\
\hline
\end{tabular}

\section{Jenis Kelamin Responden}

Tabel 1 menunjukkan bahwa responden tuberkulosis dengan sputum BTA $(+)$ dan sputum BTA (-) lebih banyak pada laki-laki daripada perempuan. Penelitian ini sejalan dengan penelitian Lestari, et al. (2011), Kurniasari (2012) dan Buntuan (2014) yang menyatakan bahwa sebagian besar subjek penderita tuberkulosis berjenis kelamin laki-laki.

\section{Usia Responden}

Menurut hasil penelitian jenis kelamin yang tersaji pada Tabel 1 menunjukkan bahwa kategori terbanyak penderita tuberkulosis dengan sputum BTA (+) maupun sputum BTA (-) adalah usia 30-49 tahun. Hal ini sejalan dengan penelitian Kasim (2012) yang menyatakan bahwa penderita tuberkulosis terbanyak adalah pada kategori usia 30-49 tahun.

Penelitian Sari dan Fauziah (2014) menyatakan bahwa $74,4 \%$ penderita tuberkulosis terjadi pada usia produktif. Jumlah kasus tuberkulosis terbanyak adalah usia $20-29$ tahun $(46,8 \%)$, sedangkan jumlah kasus tuberkulosis paling sedikit terjadi pada usia diatas 60 tahun (Soetikno dan Derry, 2011). Hal ini tidak jauh berbeda dengan hasil penelitian lain bahwa persentase terkecil penderita tuberkulosis terjadi pada usia $\geq 65$ tahun (Sihombing, et al., 2012).

\section{Tingkat Kecukupan Energi}

Hasil analisis uji Mann Whitney pada Tabel 1 menunjukkan perbedaan yang signifikan $(p=0,026)$ antara tingkat kecukupan energi responden tuberkulosis dengan sputum BTA $(+)$ dan sputum BTA (-). Median (min;maks) dari tingkat kecukupan energi penderita tuberkulosis dengan 
Tabel 2. Distribusi tingkat kecukupan dan status gizi responden tuberkulosis dengan sputum $\mathrm{BTA}(+)$ dan sputum BTA $(-)$

\begin{tabular}{|c|c|c|c|c|c|}
\hline \multirow{3}{*}{$\begin{array}{c}\text { Tingkat } \\
\text { kecukupan }\end{array}$} & \multicolumn{4}{|c|}{ Tuberkulosis } & \multirow{3}{*}{ Nilai $p$} \\
\hline & \multicolumn{2}{|c|}{ BTA $(+)$} & \multicolumn{2}{|c|}{ BTA (-) } & \\
\hline & $\mathbf{n}$ & $\%$ & $\mathbf{n}$ & $\%$ & \\
\hline \multicolumn{6}{|l|}{ Energi } \\
\hline Baik & 6 & 24 & 3 & 12 & \\
\hline Sedang & 0 & 0 & 2 & 8 & \\
\hline Kurang & 19 & 76 & 20 & 80 & \\
\hline $\begin{array}{c}\text { Median } \\
\text { (min; maks) }\end{array}$ & \multicolumn{2}{|c|}{$\begin{array}{c}54,6 \\
(8,7 ; 114,2)\end{array}$} & \multicolumn{2}{|c|}{$\begin{array}{c}74,9 \\
(19,3 ; 103,5)\end{array}$} & 0,026 \\
\hline \multicolumn{6}{|l|}{ Protein } \\
\hline Baik & 5 & 20 & 7 & 28 & \\
\hline Sedang & 0 & 0 & 10 & 40 & \\
\hline Kurang & 20 & 80 & 8 & 32 & \\
\hline $\begin{array}{c}\text { Median } \\
\text { (min; maks) }\end{array}$ & \multicolumn{2}{|c|}{$\begin{array}{c}72,8 \\
(8,5 ; 138,8)\end{array}$} & \multicolumn{2}{|c|}{$\begin{array}{c}88,1 \\
(73,7 ; 177,3)\end{array}$} & 0,001 \\
\hline \multicolumn{6}{|l|}{ Lemak } \\
\hline Baik & 10 & 40 & 9 & 36 & \\
\hline Sedang & 0 & 0 & 5 & 20 & \\
\hline Kurang & 15 & 60 & 11 & 44 & \\
\hline $\begin{array}{c}\text { Median } \\
\text { (min; maks) }\end{array}$ & \multicolumn{2}{|c|}{$\begin{array}{c}58,0 \\
(4,2 ; 141,5)\end{array}$} & \multicolumn{2}{|c|}{$\begin{array}{c}80,4 \\
(70,2 ; 126,1)\end{array}$} & 0,029 \\
\hline \multicolumn{6}{|l|}{ Karbohidrat } \\
\hline Baik & 3 & 8 & 7 & 28 & \\
\hline Sedang & 0 & 0 & 0 & 0 & \\
\hline Kurang & 22 & 82 & 18 & 72 & \\
\hline $\begin{array}{c}\text { Median } \\
\text { (min; maks) }\end{array}$ & \multicolumn{2}{|c|}{$\begin{array}{c}48,2 \\
(6,6 ; 123,3) \\
\end{array}$} & \multicolumn{2}{|c|}{$\begin{array}{c}74,5 \\
(19,8 ; 157,5)\end{array}$} & 0,000 \\
\hline \multicolumn{6}{|l|}{ Status Gizi } \\
\hline Kurus & 24 & 96 & 18 & 72 & \\
\hline Normal & 1 & 4 & 7 & 28 & \\
\hline Lebih & 0 & 0 & 0 & 0 & \\
\hline $\begin{array}{c}\text { Median } \\
\text { (min; maks) }\end{array}$ & $(12$, & & $(10$ & $\begin{array}{l}9 \\
21,9)\end{array}$ & 0,022 \\
\hline
\end{tabular}

sputum BTA (-) adalah 74,9 $(19,3 ; 103,5)$ lebih tinggi dibandingkan dengan penderita tuberkulosis dengan sputum BTA $(+)$ adalah $54,6(8,7 ; 114,2)$. Hal ini menunjukkan penderita tuberkulosis dengan sputum BTA $(+)$ memiliki tingkat kecukupan energi yang lebih rendah daripada penderita tuberkulosis dengan sputum BTA (-).

Tingkat kecukupan energi responden tuberkulosis mayoritas berada pada kategori kurang, baik tuberkulosis dengan sputum BTA $(+)$ maupun sputum BTA (-). Hal ini disebabkan karena mayoritas responden tuberkulosis tidak menjalankan diet tepat yaitu Tinggi Kalori Tinggi Protein (TKTP).

Asupan energi diperoleh dari konsumsi makanan seseorang sehari-hari untuk menutupi pengeluaran energi, baik orang sakit maupun orang sehat, konsumsi pangan harus mengandung energi yang cukup sesuai dengan kebutuhannya. Kebutuhan energi mengalami penurunan 5\% setiap 10 tahun (Adriani dan Wirjatmadi, 2012).

Keseimbangan energi dapat dicapai apabila energi melalui makanan yang masuk ke dalam tubuh sama dengan energi yang dikeluarkan, agar mampu mencapai berat badan yang normal. Jika pengeluaran energi melebihi asupan energi, maka berat badan akan turun. Hal ini disebabkan karena tingginya pengeluaran energi sedangkan asupan energi kurang dari kebutuhan. Kondisi ini disebabkan oleh beberapa faktor, di antaranya karena penyakit infeksi, demam dan trauma fisik atau pembedahan mengalami peningkatan Basal Metabolic Rate (Gandy, et al., 2014).

\section{Tingkat Kecukupan Protein}

Hasil analisis uji Mann Whitney pada Tabel 1 menunjukkan perbedaan yang signifikan $(p=0,001)$ antara tingkat kecukupan protein responden dengan sputum BTA (+) dan sputum BTA (-). Tingkat kecukupan protein responden tuberkulosis dengan sputum BTA $(+)$ mayoritas $(80 \%)$ berada pada kategori kurang, sedangkan responden tuberkulosis dengan sputum BTA (-) paling banyak (40\%) berada pada kategori sedang.

Median (min;maks) dari tingkat kecukupan protein penderita tuberkulosis dengan sputum BTA $(+)$ adalah $72,8(8,5 ; 138,8)$ lebih rendah dibandingkan dengan penderita tuberkulosis dengan sputum BTA (-) 88,1 $(73,7 ; 177,3)$. Hal ini menunjukkan bahwa pada penderita tuberkulosis sputum BTA $(+)$ memiliki tingkat kecukupan protein lebih rendah daripada penderita tuberkulosis dengan sputum BTA (-).

Penelitian ini sejalan dengan penelitian Adriani, et al. (2015) yang memaparkan bahwa asupan protein yang dikonsumsi oleh pasien tuberkulosis berbeda dengan yang tidak tuberkulosis. Rata-rata konsumsi protein lebih tinggi pada kelompok yang tidak tuberkulosis daripada kelompok penderita tuberkulosis. Penelitian lain yang telah dilakukan oleh Lazulfa (2013) di Rumah Sakit Paru Pamekasan menyebutkan bahwa sebagian besar responden tuberkulosis memiliki tingkat kecukupan protein 
kurang. Kondisi ini berbeda dengan penderita tuberkulosis pada anak yang mayoritas mempunyai asupan protein berlebih (Purnasari, 2011).

Garib dan Parveen (2011) mengungkapkan kecukupan protein yang dianjurkan untuk seseorang umumnya berbeda-beda, tergantung pada berat badan, usia dan jenis kelamin serta infeksi yang diderita. Selain sebagai zat pembangun, protein juga berfungsi untuk pertumbuhan dan pembentukan $\mathrm{Hb}$ darah, sebagai alat transportasi hemoglobin yang mengangkut oksigen pada otot (myoglobin) untuk diangkut kedalam plasma darah bersama dengan transferin aktif dan disimpan di dalam hati (Adhi, et al., 2010).

\section{Tingkat Kecukupan Lemak}

Hasil analisis uji Mann Whitney pada Tabel 1 menunjukkan perbedaan yang signifikan $(\mathrm{p}=0,029)$ antara tingkat kecukupan lemak responden tuberkulosis dengan sputum BTA $(+)$ dan sputum BTA (-). Median (min;maks) dari tingkat kecukupan lemak penderita tuberkulosis dengan sputum BTA (-) adalah 80,4 (70,2;126,1) lebih tinggi dibandingkan pada penderita tuberkulosis dengan sputum BTA $(+)$ yaitu $58,0(4,2 ; 141,5)$. Hal ini menunjukkan bahwa penderita tuberkulosis sputum BTA (-) memiliki tingkat kecukupan lemak lebih tinggi dibandingkan pada penderita tuberkulosis dengan sputum BTA $(+)$.

Tingkat kecukupan lemak responden baik tuberkulosis dengan sputum BTA $(+)$ maupun dengan tuberkulosis dengan sputum BTA (-) mayoritas berada pada kategori analisis uji Mann Whitney pada Tabel 1 menunjukkan perbedaan yang kurang. Pada pasien tuberkulosis dengan sputum BTA $(+)$ sebesar $60 \%$ dan pada pasien dengan sputum BTA (-) sebesar $44 \%$.

Penelitian ini sejalan dengan penelitian Adriani, et al. (2015) bahwa asupan lemak yang dikonsumsi oleh pasien tuberkulosis berbeda dengan yang tidak menderita tuberkulosis. Ratarata konsumsi lemak lebih tinggi pada kelompok yang tidak tuberkulosis daripada kelompok tuberkulosis. Tingkat kecukupan lemak responden mayoritas berada pada kategori kurang (Lazulfa, 2013).

Pada dasarnya lemak berfungsi sebagai pelarut bagi vitamin A, D, E, K dan juga berfungsi sebagai sumber energi dan mampu menyediakan kalori 2,25 kali lebih banyak daripada yang diberikan oleh karbohidrat atau protein. Lemak lebih banyak disimpan sebagai cadangan energi, sehingga meskipun lemak menghasilkan energi yang terbesar, tapi lemak bukanlah sebagai penghasil energi yang utama (Riandari, 2007).

\section{Tingkat Kecukupan Karbohidrat}

Hasil signifikan $(\mathrm{p}=0,000)$ antara tingkat kecukupan karbohidrat responden dengan tuberkulosis dengan sputum BTA $(+)$ dan sputum BTA (-). Median (min;maks) dari tingkat kecukupan karbohidrat pada penderita tuberkulosis dengan sputum BTA (-) adalah 74,5 $(19,8 ; 157,6)$ lebih tinggi dibandingkan tuberkulosis dengan sputum BTA $(+)$ yaitu 48,2 $(6,7 ; 123,3)$. Hal ini menunjukkan bahwa tuberkulosis sputum BTA (-) memiliki tingkat kecukupan karbohidrat lebih tinggi dibandingkan tuberkulosis dengan sputum BTA $(+)$.

Hasil tersebut sejalan dengan penelitian yang dilakukan oleh Adriani, et al. (2015) bahwa asupan karbohidrat yang dikonsumsi oleh pasien tuberkulosis berbeda dengan yang tidak menderita tuberkulosis. Rata-rata konsumsi karbohidrat pada kelompok yang tidak tuberkulosis lebih tinggi daripada yang kelompok tuberkulosis.

Hasil penelitian ini menunjukkan tingkat kecukupan karbohidrat responden mayoritas berada pada kategori kurang, baik pasien tuberkulosis dengan sputum BTA $(+)$ maupun dengan sputum BTA (-). Sebanyak $82 \%$ pasien tuberkulosis dengan sputum BTA $(+)$, sedangkan pada responden tuberkulosis dengan sputum BTA $(-)$ adalah sebanyak $52 \%$.

Penelitian yang dilakukan oleh Lazulfa (2013) menyatakan bahwa seluruh responden penderita tuberkulosis memiliki asupan karbohidrat rendah dan tingkat kecukupan karbohidratnya berada pada kategori kurang/ defisit (100\%). Gejala malaise sering ditemukan pada penderita tuberkulosis berupa anoreksia (tidak ada nafsu makan), gejala malaise ini semakin lama akan semakin berat dan gejalanya dapat hilang dan timbul secara tidak teratur (Sudoyo, et al., 2009).

Muchtadi (2014) mengemukakan bahwa karbohidrat sebagai sumber energi utama yang 
paling murah karena glukosa yang dihasilkan merupakan sumber energi utama bagi jaringan syaraf dan paru-paru. Hubungan antara karbohidrat dan lemak dalam diet bersifat timbal-balik, karena diet yang kaya akan lemak memiliki kadar karbohidrat yang rendah, begitu juga sebaliknya (Gandy, et al., 2014).

Seseorang yang memiliki kelainan pernafasan atau gejala klinis berupa sesak adalah akibat dari adanya penurunan fungsi alveoli paru dalam melakukan pertukaran antara $\mathrm{O} 2$ dan $\mathrm{CO} 2$, akibatnya perfusi $\mathrm{O} 2$ pada seluruh jaringan tubuh juga berkurang. Pembatasan pemberian karbohidrat dapat diterapkan karena karbohidrat memproduksi CO2 lebih banyak (Hartono, 2012).

\section{Status Gizi Berdasarkan Indeks Massa Tubuh}

Hasil analisis uji Mann Whitney pada Tabel 1 menunjukkan perbedaan yang signifikan $(p=0,022)$ antara status gizi pasien tuberkulosis dengan sputum BTA $(+)$ dan sputum BTA (-).

Median (min;maks) dari Indeks Massa Tubuh (IMT) pada pasien tuberkulosis sputum BTA (-) adalah $16,9(10,8 ; 21,9)$ lebih tinggi dibandingkan dengan pasien tuberkulosis sputum BTA $(+)$ adalah $15,3(12,8 ; 19,5)$. Hal ini menunjukkan bahwa IMT pasien tuberkulosis dengan sputum BTA (-) lebih tinggi daripada pasien tuberkulosis dengan sputum BTA $(+)$. Namun status gizi responden penderita tuberkulosis dengan sputum BTA (+) maupun sputum BTA (-) mayoritas berada pada kategori kurus.

Konsumsi makan yang kurang dari kebutuhan menyebabkan kekurangan kalori, protein, vitamin dan zat gizi lain. Keadaan ini mempengaruhi status gizi seseorang yang berdampak pada daya tahan tubuhnya. Kerentanan terhadap penyakit, termasuk infeksi tuberkulosis adalah akibat daya tahan tubuh yang rendah (Naga, 2012).

Penelitian ini tidak sejalan dengan penelitian Rukmini dan Chatarina (2011) yang menyatakan bahwa sebagian besar penderita tuberkulosis berstatus gizi baik dengan IMT 18,5-24,9. Penelitian Sari dan Fauziah (2014) memaparkan hasil bahwa mayoritas penderita tuberkulosis memiliki nilai IMT $<18,5$ (status gizi kurang) (Budiyanto, 2014).
Menurut Pratomo, et al. (2012) bahwa keadaan malnutrisi pada penderita tuberkulosis dapat menurunkan masa kesembuhan serta lebih meningkatkan angka kematian apabila dibandingkan dengan penderita tuberkulosis yang tidak mengalami malnutrisi. Malnutrisi yang terjadi pada penderita infeksi tuberkulosis berhubungan dengan keterlambatan penyembuhan dan peningkatan angka kematian serta risiko kekambuhan dan kejadian hepatitis akibat obat anti tuberkulosis (OAT). Tingkat kekambuhan ini meningkat pada subjek dengan IMT $<18,5$ (Gupta, et al., 2009).

Penelitian yang dilakukan di Sulawesi oleh Agustina, et al. (2015) menunjukkan tidak adanya perbedaan asupan zat gizi makro yang dikonsumsi terhadap status gizi responden yang diteliti. Pemberian obat anti tuberkulosis dan suplemen gizi tertentu secara teratur menjadi trending act dalam program peningkatan asupan gizi agar dapat meningkatkan nilai IMT penderita tuberkulosis, sehingga penderita dapat memperoleh percepatan menuju masa kesembuhannya (Tana dan Ghani, 2014).

Indeks Massa Tubuh (IMT) merupakan pengukuran yang dilakukan untuk mengetahui keadaan status gizi orang dewasa. Penelitian yang dilakukan Muaz (2014) yang mengungkapkan bahwa responden dengan IMT kurang dapat lebih beresiko sebesar 2,5 kali menderita penyakit tuberkulosis dibandingkan responden yang berstatus IMT baik. Faktor kurang gizi meningkatkan angka kesakitan/ kejadian tuberkulosis, terutama tuberkulosis paru, sehingga masyarakat dengan status gizi kurang, lebih beresiko terjangkit infeksi tuberkulosis daripada berstatus gizi baik (Toyalis, 2010)

\section{KESIMPULAN DAN SARAN}

Berdasarkan hasil penelitian yang telah dilakukan dapat disimpulkan bahwa tingkat kecukupan (energi, protein, lemak dan karbohidrat) dan status gizi responden tuberkulosis sputum BTA (-) memiliki perbedaan yang nyata dengan responden tuberkulosis sputum BTA $(+)$.

Diharapkan agar responden lebih meningkatkan pengetahuan mengenai kesehatannya, terlebih 
mengenai penyakit tuberkulosis, karena penularan tuberkulosis sangat mengancam kesehatan tubuh. Peningkatan konsumsi zat gizi makro dapat dilakukan dengan cara pemberian makanan jenis apapun yang paling disukai, terutama makanan yang mengandung tinggi energi dan protein dengan porsi kecil tetapi sering. Meskipun mengalami penurunan nafsu makan, akan tetapi kebutuhan energi dan zat gizi harus tetap terpenuhi agar tidak memperberat infeksi penyakitnya, demi tercapainya kesehatan yang optimal dalam mencegah terjadinya morbiditas dan mortalitas akibat infeksi tuberkulosis.

\section{DAFTAR PUSTAKA}

Adhi, KT., Wirjatmadi, B., Adriani, M. (2010). Perbedaan kadar seng serum dan kadar c-reactive protein pada anak balita dengan kadar serum retinol normal dan tidak normal. Jurnal Gizi Klinik Indonesia, 7(2), 58-63. Diakses dari https:// www.ijcn.or.id/download/ Vo17No2Nov2010/KadekTA.pdf.

Adriani, M., dan Wirjatmadi, B. (2012). Peranan gizi dalam siklus kehidupan. Jakarta: KENCANA.

Adriani, M., Yoanita, IK., Eva, IF., Bambang, W. (2015). Level of zinc, retinol, blood macrophages, t-lymphocytes and Immunoglobulin-G in children with tuberculosis and non tuberculosis. J Nutr Disorders, 10(4172), 2161 - 0509. doi: 10.4172/2161-0509.S1-003.

Agustina, W., Jus'at, I., Mulyana, EY., Kuswari, M. (2015). Asupan zat gizi makro dan serat menurut status gizi anak usia 6-12 tahun di Pulau Sulawesi. J. Gizi Pangan, 10(1), 63-70. Diakses dari http://journal.ipb.ac.id/index.php/ jgizipangan/article/view/9314.

Al Arif, D., Fauzi, ZA., Andrini, F. (2015). Angka kejadian tuberkulosis paru pada pasangan suami-istri penderita tuberkulosis paru bta positif di Poliklinik Paru RSUD Arifin Achmad. JOM FK, 2(2), 1-13. Diakses dari http://download.portalgaruda.org/article.p hp article $=294692 \& \mathrm{val}=6449 \&$ title $=$ ANG KA\%20KEJADIAN\%20tuberkulosis\%20 paru $\% 20$ pada $\% 20$ pasangan $\% 20$ suami-Istri $\% 20$ pnederita $\% 20$ tuberkulosis $\% 20$ paru $\% 20 \mathrm{bta} \%$ 20positif\%20di\%20poliklinik\%20paru\%20 rsud\%20arifin\%20achmad.
Amaliah, R. (2012). Faktor-faktoryang berhubungan dengan kegagalan konversi penderita TB paru bta positif pengobatan fase intensif di Kabupaten Bekasi Tahun 2010. (Master's Thesis, Universitas Indonesia, Depok) Diakses darihttp://lib.ui.ac. id/file?file=digital/20313567-T31309-Faktorfaktor.pdf.

Ben-Salma, W., Ben-Kahla, I., Marzouk, M., Farjeni, A., Ghezal, S., Ben-Said, M., Boukadida, J. (2009). Rapid detection of mycobacterium tuberculosis in sputum by patho-TB kit in comparison with direct microscopy and culture. Diagnostic Microbiol Infect Dis, 65(3), 232-5. doi:10.1016/j. diagmicrobio.2009.07.021.

Budiyanto, H. (2014). Perbedaan frekuensi makan dan status gizi pasien TB paru sebelum dan sesudah diberikan konseling gizi di Balai Besar Kesehatan Paru Masyarakat (BBKPM) Surakarta. (Skripsi, Universitas Muhammadiyah Surakarta, Surakarta) Diakses dari http:// eprints.ums.ac.id/32137/13/NASKAH $\% 20$ PUBLIKASI.pdf.

Buntuan, V. (2014). Gambaran Basil Tahan Asam (BTA) positif pada penderita diagnosa klinis tuberkulosis paru di rumah sakit islam Sitti Maryam Manado periode Januari 2014 s/d Juni 2014. Jurnal e-Biomedik (eBM), 2(2), 1-8. Diakses dari https://ejournal.unsrat.ac.id/index. php/ebiomedik/article/view/5604/5138.

Departemen Kesehatan RI. (2007). Pedoman Nasional Penanggulangan Tuberculosis. Jakarta: Departemen Kesehatan Republik Indonesia.

Gandy, JW., Madden, A., Holdsworth, M. (2014). Gizi dan dietetika. Ed 2. Jakarta: Buku Kedokteran EGC

Garib dan Parveen, R. (2011). Energy and macro nutrient intake and dietary pattern among school children in Bahrain. Nutr J, 10(62), 1-12. Diakses dari http://www.ncbi.nlm.nih.gov/pmc/ articles/PMC3123629/.

Gupta K,B., Gupta, R., Atreja, A., Verma, M., Vishvkarma, S. (2009). Tuberculosis and nutrition. Lung India, 26(1), 9-16. Diakses dari http://www.lungindia.com/downloadpdf. asp?issn $=0970-2113$; year $=20 \quad 09$; volume $=26$; issue $=1 ;$ spage $=9 ;$ epage $=16$; aulast $=$ Gupta;typ $\mathrm{e}=2$.

Hartono, Andry. 2012. Terapi gizi dan diet rumah sakit, Ed. 2. Jakarta: EGC. 
Kasim, H. (2012). Hubungan luas lesi pada gambaran radiologi toraks dengan kepositivan pemeriksaan sputum BTA (Basil Tahan Asam) pada pasien tuberkulosis paru dewasa kasus baru di BBKPM Surakarta. (Skripsi, Universitas Muhammadiyah, Surakarta) Diakses dari https:// eprints.ums.ac.id/22750/13/NASKAH_ PUBLIKASI.pdf.

Kementrian Kesehatan RI. (2010). Laporan Riset Kesehatan Dasar Tahun 2010. Jakarta: Badan Penelitian dan Pengembangan Kesehatan Kementrian Kesehatan RI.

Kementrian Kesehatan RI. (2013). Laporan Riset Kesehatan Dasar Tahun 2013. Jakarta: Badan Penelitian dan Pengembangan Kesehatan Kementrian Kesehatan RI.

Kurniasari, RAS., Suhartono., Cahyo, K. (2012). Faktor risiko kejadian tuberkulosis paru di Kecamatan Baturetno Kabupaten Wonogiri. Media Kesehatan Masyarakat Indonesia, 11(2), 198-204. Diakses darihttp://www. ejournal.undip.ac.id/index.php/mkmi/article/ view/5396.

Lazulfa, RWA. (2013). Hubungan tingkat konsumsi energi, karbohidrat, protein, lemak dan vitamin B6 terhadap status gizi pasien TBC paru rawat inap di Rumah Sakit Paru Pamekasan-Madura. (Karya Tulis Ilmiah tidak diterbitkan). STIKES Karya Husada Kediri, Kediri.

Lestari, P., Endaryanto, A., Sahiratmadja, E., Suharto. (2011). Status gizi dan status besi anak kontak tuberkulosis serta peranannya dalam kejadian sakit (Nutrition and iron status in children with TB parents, their role on infection and disease). JBP, 13(2), 131136. Diakses dari:// https://journal.unair.ac.id/ download-fullpapers-Vol\%2013\%20No\%20 2\%20Mei\%202011-7.pdf.

Mahdiana, R. (2010). Mengenal, mencegah dan mengobati penularan penyakit dari infeksi. Yogyakarta: Citra Pustaka.

Manalu, HSP. (2010). Faktor-faktor yang mempengaruhi kejadian TB dan upaya penanggulangannya (Factors affecting the occurrence of pulmonary $T B$ and efforts to overcome). Jumal Ekologi Kesehatan, 9(4), 1340-1346. Diakses dari http://ejournal. litbang. depkes.go.id/index.php/jek/article/ view/1598/1040.

Muaz, F. (2014). Faktor-faktor yang mempengaruhi kejadian tuberkulosis paru Basil Tahan Asam Positif di Puskesmas wilayah Kecamatan
Serangkota Serang Tahun 2014. (Skripsi, Universitas islam negeri Syarif Hidayatullah, Jakarta) Diakses dari http://repository.uinjkt. ac.id/dspace/bitstream/123456789/25734/1/ FARIS\%20MUAZ.pdf.

Muchtadi, D. (2014). Pengantar ilmu gizi. Bandung: ALFABETA.

Naga, S. (2012). Buku panduan lengkap ilmu penyakit dalam. Jogjakarta: DIVA Press.

Pratomo, IP., Burhan, E., Tambunan, V. (2012). Malnutrisi dan tuberkulosis. JIndon Med Assoc, 62(230), 7-12. Diakses dari .

Purnasari, G. (2011). Anemia pada penderita tuberkulosis paru anak dengan berbagai status gizi dan asupan zat gizi. (Skripsi, Universitas Dipenogoro, Semarang) Diakses dari https:// core.ac.uk/download/files/379/11731608.pdf.

Riandari, H. (2007). Sains biologi, cetakan 2. Solo: PT Tiga Serangkai Pustaka Mandiri.

Rukmini and Chatarina, UW. (2011). Faktorfaktor yang berpengaruh terhadap kejadian tb paru dewasa di indonesia (analisis data Riset Kesehatan Dasar Tahun 2010). Public Health, 14(4), 322-326. Diakses dari http://ejournal. litbang.depkes.go.id/index.php/hsr/article/ view/1369/ 2193.

Sari, IS., dan Fauziah, M. (2014). Faktor risiko yang berhubungan dengan kejadian TB paru BTA $(+)$ di wilayah kerja Puskesmas Petamburan Kota Jakarta Pusat Tahun 2012. Jurnal kedokteran dan kesehatan, 10(2), 0216-3942.

Sihombing, H., Sembiring, H., Amir, Z., Sinaga, Y, M, B. (2012). Pola resistensi primer pada penderita TB paru kategori I di RSUP H. Adam Malik Medan. Respir Indo, 32(3), 138145. Diakses dari https:// repository.usu.ac.id/ bitstream/123456789/33363/7/Cover.pdf.

Soetikno, DR., Derry. (2011). Kesesuaian antara foto toraks dan mikroskopis sputum pada evaluasi respons pengobatan tuberkulosis paru setelah enam bulan pengobatan. $M K B, 43(3)$, 140-145. Diakses dari http://unpad.ac.id.

Srikanth, P., Kamesh, S., Daley, P. (2009). Bleach optimization of sputum smear microscopy for pulmonary tuberculosis. Indian J Tuberc, 56(4), 178-184. Diakses dari http://Mahidol.ac.th.

Sudoyo,WA., Setyohadi, B., Alwi, I. (2009). Buku ajar ilmu penyakit dalam. Jakarta: Interna Publishing.

Supariasa, I.D.N., Bakri, B., Fajar, I. (2014). Penilaian status gizi. Jakarta: Buku Kedokteran EGC. 
Susilayanti, Eni Yulvia., Medison, Irvan., Erkadius. (2014). Profil penderita penyakit tuberkulosis paru BTA positif yang ditemukan di BP4 Lubuk Alung periode Januari 2012 -Desember 2012. Jurnal Kesehatan Andalas, 3(2), 151-155. Diakses dari http://jurnal.fk.unand.ac.id.

Tana, L., dan Ghani, L. (2014). Gambaran TB paru pekerja puskesmas di enam kabupaten kota di Indonesia (Pulmonary tuberculosis among primary health center workers in 6 districts in Indonesia). Buletin Penelitian Sistem
Kesehatan, 17(3), 319-325. Diakses dari https:// oaji.net/articles/2015/820-1432783729.pdf.

Toyalis. (2010). Faktor-faktor yang berhubungan dengan terjadinya penyakit TB paru di Provinsi Banten 2009-2010. (Unpublished master's thesis). Universitas Respati Indonesia, Jakarta.

WHO. (2014). Global tuberculosis report 2014. Switzerland: Departement of nutrition for Health and Development (NHD). Diakses dari http://apps.who.int/iris/ bitstream/10665/1370 94/1/9789241564809_eng.pdf. 